\title{
Identifying Crabapple Cultivars by Isozymes
}

\author{
Robert D. Marquard and Charlotte R. Chan \\ The Holden Arboretum, 9500 Sperry Road, Kirtland, OH 44094
}

\begin{abstract}
Additional index words. Malus, isoenzyme, starch gel electrophoresis
Abstract. Forty-five crabapple (Malus spp.) cultivars were evaluated for 16 isozyme systems by starch gel electrophoresis. Of the 16 systems evaluated, 6 were useful in separating among cultivars. Enzyme systems used to distinguish among the cultivars included alcohol dehydrogenase, aspartate aminotransferase, malate dehydrogenase, 6-phosphogluconate dehydrogenase, phosphoglucoisomerase, and shikimate dehydrogenase. Each enzyme system produced one well-resolved polymorphic region except for 6-phosphogluconate dehydrogenase, which produced two. Most crabapple selections could be identified when all six enzymes were evaluated. Alcohol dehydrogenase had the most diagnostic banding patterns useful for cultivar identification.
\end{abstract}

Crabapples are a popular group of ornamental trees that are morphologically very diverse. Nearly 700 crabapple cultivars have been named (Dirr, 1990), constituting a genetic background derived from many species (Fiala, 1994). Crabapple nursery stock can be difficult to identify when young, parentage often is unknown, and synonymy may exist among named cultivars. In addition, species of the genus $M$ alus freely interbreed (Korban, 1986). Heritable biochemical traits such as isozymes could help remedy identification problems in crabapples. Isozymes are largely unaffected by the environment, simply inherited, relatively inexpensive to analyze, and have been widely used to verify cultivars (Arulsekar and Parfitt, 1986; Greer et al., 1993; Peirce and Brewbaker, 1973; Tanksley and Orton, 1983).

While cultivated apples have been evaluated for isozyme differences (Menendez et al., 1986; Samimy and Cummins, 1992; Weeden and Lamb, 1985, 1987), little if any work has been conducted with crabapples. Given the polyploid origin of $\mathrm{M}$ alus spp. as postulated by Chevreau and Gallet (1985) and Chevreau and Laurens (1987) and the multi-species complex from which they are derived (Fiala, 1994), crabapples should be sufficiently diverse to be exploited by isozyme analyses. The objective of this study was to determine if crabapple cultivars can be differentiated by polymorphic isozyme patterns.

\section{Materials and Methods}

Dormant bud tissue was collected from 45 crabapple selections from the collections at The Holden Arboretum during Fall 1992 and 1993 and leaf tissue was collected in Spring 1994. Tissue samples were stored at $4 \mathrm{C}$ for no more than 1 week before analysis. About $200 \mathrm{mg}$ of tissue (bud or leaf) was macerated using a glass pestle with ground glass in a chilled spot plate with about $65 \mu \mathrm{l}$ of extraction buffer (Wendel and Parks, 1982). Crude protein extracts were absorbed onto filter paper wicks and loaded onto $11.5 \%$ starch gels using standard procedures (Vallejos, 1983).

Crude protein extracts of individual samples were loaded onto each of three gels to maximize the resolution of isozymes. Three buffer systems were used, including a morpholine-citric acid system, pH 6.1 (Conkle et al., 1982) designated MC; a lithium hydroxide-boric acid system, $\mathrm{pH} 8.1$ (Cheliak and Pitel, 1984), designated cheliak-B; and a histidine-Tris system, pH 7.0 (Cheliak and Pitel, 1984), designated Cheliak-H.

Received for publication 5 Dec. 1994. Accepted for publication 13 Apr. 1995. The cost of publishing this paper was defrayed in part by the payment of page charges. Under postal regulations, this paper therefore must be hereby marked advertisement solely to indicate this fact.
For electrophoresis, gels were chilled to $4 \mathrm{C}$ and initially powered at 100 to 150 volts. Sample wicks were removed after $20 \mathrm{~min}$, and electrophoresis continued for 3 to $6 \mathrm{~h}$ at about 300 volts. Gels were sliced horizontally and the top most slice was discarded. The following enzyme systems were stained and analyzed: aconitase, aminoaspartate transferase (AAT; EC 2.6.1.1), acid phosphatase, alcohol dehydrogenase (ADH; EC 1.1.1.1), diaphorase, colorimetric esterase, glucose-\&phosphate dehydrogenase, isocitric dehydrogenase, leucine aminopeptidase, malate dehydrogenase (MDH; EC 1.1.1.37), malic enzyme, peroxidase (PER; EC 1.11.1.7), phosphoglucoisomerase (PGI; EC 5.3.1.9), phosphoglucomutase (PGM; EC 2.7.5.1), 6-phosphogluconate dehydrogenase (6-PGD; EC 1.1.1.44), and shikimate dehydrogenase (SKDH; EC 1.1.1.25). Standard stain recipes were used to elucidate the isozymes (Cheliak and Pitel 1984; Wendel and Weeden, 1989). All samples were run a minimum of three times to verify reproducibility, and tissue from 'Harvest Gold' was included as a reference on all gels.

\section{Results and Discussion}

Among the crabapple cultivars, 8 of the 16 enzymes were polymorphic, including AAT, ADH, MDH, PER, 6-PGD, PGI, PGM, and SKDH. PGM was not included in this report because of excessively complex banding patterns. Whereas PGM in plants is typically controlled by two loci (Gottlieb, 1982), banding patterns of PGM in Malus is complex and apparently controlled by five loci (Weeden and Lamb, 1987). In addition, banding expression for PGM was less intense and reliable from leaf tissue. PER expression tended to be inconsistent and was not scored here.

Best results were obtained with MDH and 6-PGD stained on the MC buffer system, AAT and PGI stained on the Cheliak-B system, and ADH and SKDH stained on the Cheliak-H system. AAT, $\mathrm{ADH}, \mathrm{MDH}, \mathrm{PGI}$, and SKDH each had one polymorphic region that was storable, whereas 6-PGD had two polymorphic regions. AAT produced one darkly stained region and four banding patterns (Fig. 1). ADH produced a fast monomorphic region and a slower polymorphic region with seven different banding patterns (Fig. 1). Six of seven phenotypes for ADH (Fig. 1 A-F) are consistent with a dimeric enzyme and a diploid individual. The ' $G$ ' phenotype, which is 5-banded and exhibited by 'Hamlet', is consistent with a polyploid individual.

MDH produced three regions of activity, including one polymorphic region with four observed phenotypes (Fig. 1). PGI exhibited two banding regions, but only the slow region was scored. Crabapple cultivars were grouped into one of three classes for PGI, including a single-, triple-, or five-banded phenotype (Fig. 1). Occasionally, two closely migrating PGI bands were observed 


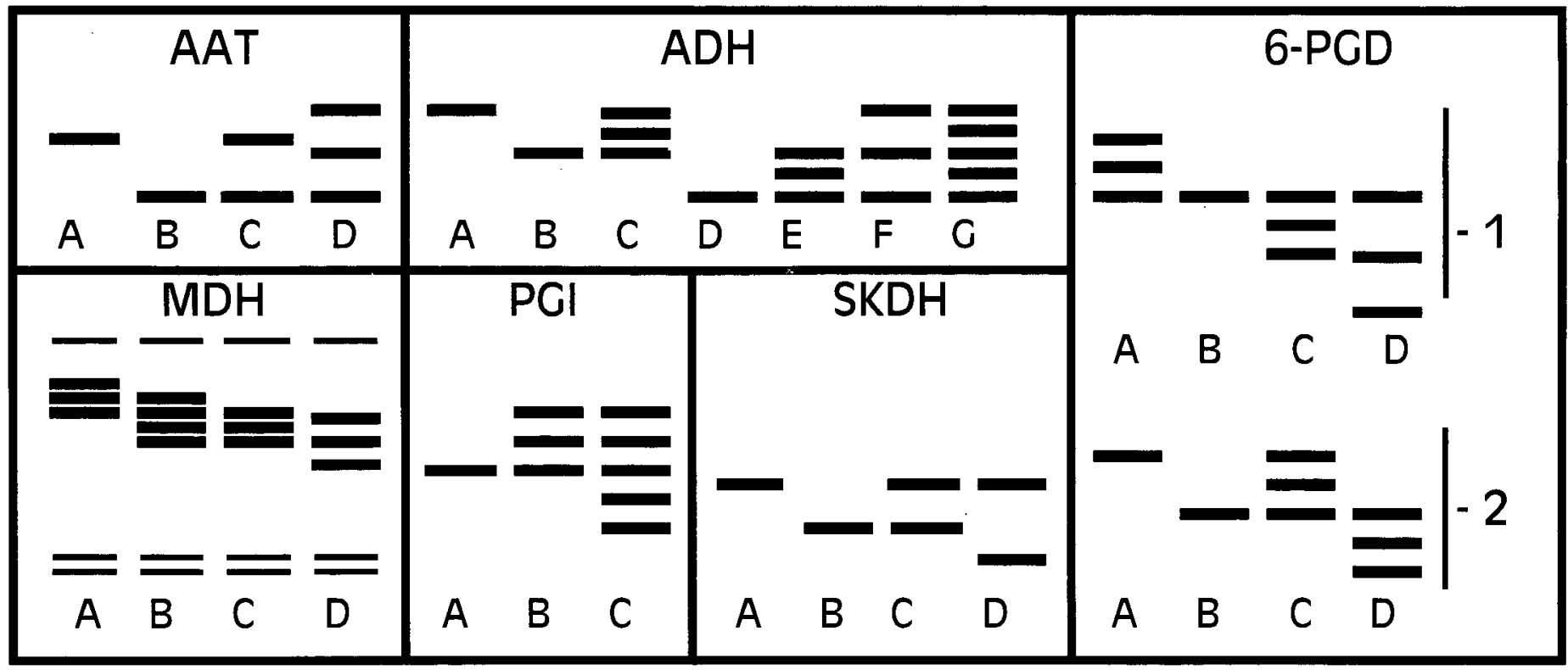

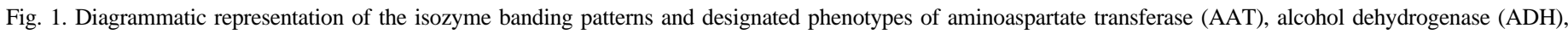

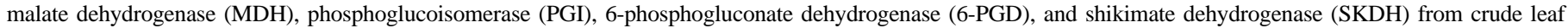
extracts from crabapples. 6-PGD produced two polymorphic regions of activity that were scored $(-1$ and -2$)$.

at a relative mobility of about $22 \%\left[\left(\mathrm{R}_{\mathrm{r}}\right)=0.221\right.$. These twin bands have a mobility similar to the single band exhibited by phenotype A (Fig. 1). For simplicity, we have grouped cultivars that produced these twin bands with cultivars that yielded a single band at $\mathrm{R}_{\mathrm{f}}=$ 0.22 .

Banding of 6-PGD was polymorphic with a fast [anodal] region designated 6-PGD-1 and a slow region designated 6-PGD-2 (Fig. 1). Each 6-PGD region produced four banding patterns consistent with a dimeric enzyme (Fig. 1). SKDH produced bands in a single region of activity with excellent resolution. SKDH patterns included either a single or double band consistent with a monomeric enzyme (Fig. 1).

$\mathrm{ADH}$, 6-PGD, and SKDH banding patterns were sufficiently simple and well-resolved that a genetic model can be suggested. That is, ADH appears to be regulated by two loci, of which one is polymorphic and controlled by at least three alleles. Two loci controlling $\mathrm{ADH}$ in Malus have been previously reported (Chevreau and Gallet, 1985; Samimy and Cummins, 1992). At least two polymorphic loci control 6-PGD in Malus (Chyi and Weeden, 1984). In crabapples, the region corresponding to 6-PGD-1 appears to be controlled by at least four alleles and 6-PGD-2 by at least three alleles. SKDH appears to be controlled by one polymorphic locus with at least three alleles.

The banding patterns of AAT and MDH were not sufficiently straightforward to suggest a genetic model without evaluating segregating populations from known parents. However, Chyi and Weeden (1984) and Weeden and Lamb (1985) reported that AAT was controlled by two loci. Weeden and Lamb (1987) reported five possible loci controlling MDH in Malus. Except for PGM, enzymes reported here were consistent in isozyme number and intensity for leaf and bud tissue.

Three observed isozyme phenotypes suggest polyploidy of five cultivars. Phenotype 'D' for AAT, 'G' for ADH, and 'C' for PGI are inconsistent for a diploid plant (Wendel and Weeden, 1989) (Fig. 1). Cultivars exhibiting possible polyploidy patterns include 'Hamlet', 'Madonna', 'Pink Satin', 'Pond Red', and 'Royal Ruby'. 'Hamlet' exhibited two isozyme phenotypes that were consistent with polyploidy (Table 1). That is, each of these cultivars produced bands in addition to what would normally be expressed by one locus from a diploid individual.

Nearly all 45 crabapple cultivars could be differentiated by isozymes (Table 1). However, three cultivar pairs had similar banding patterns including 'Eleyi' and 'Hopa', Pink Dawn' and 'Canary', and 'Silver Drift' and 'Donald Wyman'. All six enzymes were required to delineate among most cultivars. ADH had the greatest number of banding patterns (7) whereas the other enzymes had three to four patterns. Some phenotypes were more diagnostic in differentiating among cultivars. Banding patterns observed at a frequency of $<10 \%$ were arbitrarily considered diagnostic (Table 2). ADH had four diagnostic banding patterns, AAT, MDH, and SKDH each had two diagnostic patterns, and 6PGD-2 and PGI each had one. Cultivars with diagnostic banding patterns included 'Brandywine', 'Burgandy', 'Camelot', 'Dolgo', 'Doubloons', 'Hamlet', 'Lancelot', 'Madonna', 'Mollie Ann', 'Pink Satin', 'Pond Red', 'Red Barron', 'Royal Ruby', 'Selkirk', 'Sinai Fire', 'Spring Song', and 'Zumarang'.

\section{Literature Cited}

Arulsekar, S. and D.E. Parfitt. 1986. Isozyme analysis procedures for stone fruits, almonds, grape, walnut, pistachio, and fig. HortScience 21:928-933.

Cheliak, W.H. and J.A. Pitel. 1984. Techniques for starch gel electrophoresis of enzymes from forest tree species. Petawawa Natl. For. Inst. Rpt. PI-X-42.

Chevreau, E. and M. Gallet. 1985. Inheritance of pollen enzymes and polyploid origin of apple (Malus $\times$ domestica Borkh.). Theor. Appl. Genet. 71:268-277.

Chevreau, E. and F. Laurens. 1987. The pattern of inheritance in apple (Malus $\times$ domestica Borkh.): Further results from leaf isozyme analysis. Theor. Appl. Genet. 75:90-95.

Conkle, M.T., P.D. Hodgekiss, L.B. Nunnaly, and S.C. Hunter. 1982. Starch gel electrophoresis of conifer seeds: A laboratory manual. Pacific Southwest For. Range Expt. Sta., Berkeley, Calif. Tech. Rpt. PSW-64. Chyi, Y.S. and N.F. Weeden. 1984. Relative isozyme band intensities permit the identification of the $2 \mathrm{n}$ gamete parent of triploid apple cultivars. HortScience 19:818-819.

Dirr, Michael A. 1990. Manual of woody landscape plants: Their identi- 
Table 1. Cultivars of selected crabapple taxa evaluated by isozyme analysis along with the corresponding phenotype for the six enzyme systems (and seven polymorphic regions) that were evaluated. Phenotypes reported correspond to banding patterns (Fig. 1).

\begin{tabular}{|c|c|c|c|c|c|c|c|}
\hline Cultivar & AAT & $\mathrm{ADH}$ & MDH & 6-PGD-1 & 6-PGD-2 & PGI & SKDH \\
\hline$\overline{\text { Adams }}$ & B & $\mathrm{B}$ & B & $\mathrm{C}$ & B & B & $\mathrm{B}$ \\
\hline Brandywine & B & B & D & $\mathrm{C}$ & $\mathrm{C}$ & A & A \\
\hline Burgandy & B & $\mathrm{F}$ & B & B & B & A & $\mathrm{C}$ \\
\hline Camelot & $\mathrm{C}$ & A & $\mathrm{C}$ & B & B & B & B \\
\hline Canary & B & B & B & B & B & A & $\mathrm{C}$ \\
\hline David & B & B & $\mathrm{C}$ & B & B & B & B \\
\hline Dolgo & B & E & A & D & A & A & B \\
\hline Donald Wyman & B & C. & $\mathrm{C}$ & A & B & B & $\mathrm{C}$ \\
\hline Doubloons & B & $\mathrm{D}$ & $\mathrm{C}$ & B & A & A & B \\
\hline Edna Mullins & B & B & $\mathrm{C}$ & A & B & B & C \\
\hline Excaliber & $\mathrm{C}$ & B & $\mathrm{C}$ & B & $\mathrm{C}$ & B & B \\
\hline Golden Gem & $\mathrm{C}$ & B & $\mathrm{C}$ & C & B & B & $\mathrm{C}$ \\
\hline Golden Hornet & B & $\mathrm{C}$ & B & D & D & B & B \\
\hline Golden Raindrops & B & $\mathrm{C}$ & $\mathrm{C}$ & B & $\mathrm{C}$ & A & B \\
\hline Hamlet & $\mathrm{C}$ & G & $\mathrm{C}$ & B & B & $\mathrm{C}$ & B \\
\hline Harvest Gold & B & B & B & B & B & A & B \\
\hline Hopa & B & E & B & $\mathrm{C}$ & B & A & B \\
\hline Jewelberry & $\mathrm{B}$ & E & $\mathrm{C}$ & B & $\mathrm{D}$ & B & B \\
\hline Lancelot & $\mathrm{C}$ & A & $\mathrm{C}$ & A & $\mathrm{C}$ & B & $\mathrm{C}$ \\
\hline Louisa & B & B & $\mathrm{C}$ & B & B & B & $\mathrm{C}$ \\
\hline Madonna & D & B & B & B & B & A & A \\
\hline Mollie Ann & B & A & $\mathrm{C}$ & B & C & A & B \\
\hline Ormiston Roy & B & B & B & B & B & B & $\mathrm{C}$ \\
\hline Pink Cascade & B & B & B & D & B & A & $\mathrm{C}$ \\
\hline Pink Dawn & B & B & B & B & B & A & C \\
\hline Pink Satin & B & B & C & D & B & $\mathrm{C}$ & B \\
\hline Pond Red & C & E & $\mathrm{C}$ & B & B & $\mathrm{C}$ & $\mathrm{C}$ \\
\hline Prairie Maid & $\mathrm{C}$ & $\mathrm{C}$ & B & B & D & A & B \\
\hline Prairifire & $\mathrm{C}$ & B & B & B & B & B & B \\
\hline Professor Sprenger & $\mathrm{C}$ & B & B & $\mathrm{C}$ & D & B & $\mathrm{C}$ \\
\hline Profusion & B & B & $\mathrm{C}$ & $\mathrm{C}$ & D & A & B \\
\hline Purple Prince & B & $\mathrm{C}$ & $\mathrm{C}$ & B & $\mathrm{C}$ & B & B \\
\hline x purpurea Eleyi & B & B & B & $\mathrm{C}$ & B & B & B \\
\hline Red Barron & B & B & $\mathrm{C}$ & B & B & B & A \\
\hline Red Jewel & C & B & $\mathrm{C}$ & B & B & A & B \\
\hline Royal Ruby & B & $\mathrm{F}$ & $\mathrm{C}$ & B & B & $\mathrm{C}$ & $\mathrm{D}$ \\
\hline Candymint Sargent & B & $\mathrm{C}$ & $\mathrm{C}$ & $\mathrm{C}$ & $\mathrm{C}$ & B & B \\
\hline Selkirk & B & E & B & C & B & A & A \\
\hline Sentinel & C & $\mathrm{C}$ & $\mathrm{C}$ & A & B & B & $\mathrm{C}$ \\
\hline Silver Drift & B & $\mathrm{C}$ & $\mathrm{C}$ & A & B & B & $\mathrm{C}$ \\
\hline Sinai Fire & B & B & $\mathrm{C}$ & D & A & A & B \\
\hline Snow Magic & B & B & $\mathrm{C}$ & A & B & B & B \\
\hline Spring Song & B & $\mathrm{F}$ & $\mathrm{C}$ & B & B & A & $\mathrm{C}$ \\
\hline Weeping Candied Apple & $\mathrm{C}$ & B & $\mathrm{C}$ & B & B & B & B \\
\hline Zumarang & A & A & $\mathrm{C}$ & A & A & B & $\mathrm{C}$ \\
\hline
\end{tabular}

Table 2. Frequency of phenotypes observed among 45 crabappple cultivars characterized by isozyme analysis.

\begin{tabular}{lrrrrrrr}
\hline \hline Phenotype & AAT & ADH & MDH & 6-PGD-1 & 6-PGD-2 & PGI & SKDH \\
\hline A & 1 & 4 & 1 & 7 & 4 & 18 & 4 \\
B & 31 & 23 & 15 & 24 & 29 & 4 & 24 \\
C & 12 & 8 & 28 & 9 & 7 & --- & 16 \\
D & 1 & 1 & 1 & 5 & --- & -- & -- \\
E & --- & 5 & --- & --- & -- & -- \\
F & --- & --- & 1 & --- & --- & - & - \\
G & -- & & & & -- & - & - \\
\hline
\end{tabular}


fication, ornamental characteristics, culture, propagation and uses. Stipes Publishing Co., Champaign, Ill.

Fiala, J.L. 1994. Flowering Crabapple. The genus Malus. Timber Press, Portland, Ore.

Gottlieb, L.D. 1982. Conservation and duplication of isozymes in plants. Science 216:373-380.

Greer, C.E., R.E. Schutzki, A. Fernandez, and J.F. Hancock. 1993. Electrophoretic characterization of Taxus cultivars. HortTechnology $3: 430-433$.

Korban, S.S. 1986. Interspecific hybridization in Malus. HortScience 21:41-48.

Menendez, R.A., F.E. Larsen, and R. Fritts, Jr. 1986. Fingerprinting apple cultivars by electrophoretic isozyme banding patterns. J. Environ. Hort. 4:101-107.

Peirce, L.C. and J.L. Brewbaker. 1973. Applications of isozyme analysis in horticultural science. HortScience 8: 17-22.
Samimy, C. and J.N. Cummins. 1992. Distinguishing apple rootstocks by isozyme banding patterns. HortScience 27:829-831.

Tanksley, S.D. and T.J. Orton (eds.). 1983. Isozymes in plant genetics and breeding. Part B. Elsevier, Amsterdam.

Vallejos, C.E. 1983. Enzyme activity staining, p. 469-516. In: S.D. Tanksley and T.J. Orton (eds.). Isozymes in plant genetics and breeding. Part A. Elsevier, Amsterdam.

Weeden, N.F. and R.C. Lamb. 1985. Identification of apple cultivars by isozyme phenotypes. J. Amer. Soc. Hort. Sci. 110:509-515.

Weeden, N.F. and R.C. Lamb. 1987. Genetics and linkage analysis of 19 isozyme loci in apple. J. Amer. Soc. Hort. Sci. 112:865-872.

Wendel, J.F. and C.R. Parks. 1982. Genetic control of isozyme variation in Camellia japonica L.J. Hered. 73:197-204.

Wendel, J.F. and N.F. Weeden. 1989. Visualization and interpretation of plant isozymes. In: D.E. Soltis and P.S. Soltis (eds.). Isozymes in plant biology. Dioscorides Press, Portland, Ore. 